\title{
Dyskusja przed Narodowym Kongresem Nauki - refleksje
}

\begin{abstract}
STRESZCZENIE. W opracowaniu przedstawiono analizę wybranych tematów poruszanych w dyskusjach dotyczących nauki i szkolnictwa wyższego w kontekście przygotowywanej ustawy - zwanej Ustawą 2.o. Autor wybrał te tematy, które dominowały w trakcie obrad podczas dziewięciu konferencji zorganizowanych przed Narodowym Kongresem Nauki i posiedzeń Rady tego Kongresu. Tematy $\mathrm{i}$ ich analiza są punktem widzenia autora i zostały zebrane $\mathrm{w}$ formę pięciu refleksji. Przedstawiono również kilka propozycji szczegółowych rozwiązań - jeden w postaci dodatku do opracowania.
\end{abstract}

SŁOWA KLUCZOWE: nauka, szkolnictwo wyższe, Ustawa 2.0

\section{Wstęp}

Zaplanowany na 19 i 20 września Narodowy Kongres Nauki to zakończenie, a zarazem podsumowanie wielu działań, w tym wielomiesięcznej dyskusji związanej przede wszystkim z planowaną globalną reformą nauki i szkolnictwa wyższego. Ze względu na różnorodne powiązania prawnych aspektów funkcjonowania jednostek naukowych, w tym uczelni, oczywiste jest, że reformy te muszą pociągnąć za sobą zmiany w wielu innych ustawach i aktach prawnych niższego rzędu. Jest to więc zamierzenie dotyczące ogromnej części polskiego systemu prawnego. Rzecz jasna, zależeć ono będzie od głębokości proponowanych zmian i zakresu całej reformy.

W tym kontekście wyrażenie opinii czy nawet jedynie refleksji w stosunku do całości zagadnień przez jednego autora nie tylko nie jest możliwe, przy założeniu odpowiedniej ich głębszej analizy i uwzględnieniu powiązań wzajemnych, ale nawet niepotrzebne wobec bardzo szerokiej i w mojej ocenie wyczerpującej tę tematykę dotychczasowej dyskusji. Mowa tu o powszechnie dostępnych materiałach opu- 
blikowanych zarówno przez trzy zespoły eksperckie wyłonione w drodze konkursu przez Ministerstwo Nauki i Szkolnictwa Wyższego, przed i po ośmiu tematycznych comiesięcznych konferencjach przygotowawczych do NKN, a także opracowaniach zespołów tematycznych Rady NKN czy obszernych opracowaniach Konferencji Rektorów Akademickich Szkół Polskich, jak również materiałach przygotowanych przez organizacje związkowe, Obywateli Nauki oraz o wielu publikacjach prasowych i indywidualnych opracowaniach osób związanych głównie z naszym środowiskiem.

W wielości punktów widzenia i wyników przedstawionych w tych opracowaniach analiz i zgłoszonych propozycji rozwiązań trudno znaleźć „białe plamy” lub mieć niedosyt dyskusji. Mówiono o wszystkim. Najważniejsze z punktu widzenia przyszlej ustawy są wypowiedzi wicepremiera rządu, a zarazem ministra nauki i szkolnictwa wyższego dr. Jarosława Gowina, i to zarówno te na łamach prasy, jak i te na rozpoczęciu każdej z dziewięciu konferencji tematycznych czy na spotkaniach środowiskowych, a także wypowiedzi przewodniczącego Rady NKN prof. Jarosława Górniaka w trakcie tych konferencji i posiedzeń Rady. Większość z nich udokumentowana jest w materiałach z tych wydarzeń.

Moje refleksje wynikające zarówno z udziału w większości tych spotkań i wydarzeń, szeregu dyskusji w mniejszych i większych gremiach, począwszy od zespołów badawczych, poprzez poziom wydziałów i całych uczelni, do komisji sejmowych i senackich, będą dotyczyły tylko niektórych zagadnień, szczególnie mi bliskich. Muszę zaznaczyć, że jako rektor Politechniki Warszawskiej, sprawujący tę funkcję drugą kadencję, a poprzednio dziekan największego wydziału tej uczelni, tj. Wydziału Elektroniki i Technik Informacyjnych, i co istotne, wywodzący się ze szkoły dydaktycznej i naukowej prof. Andrzeja Jakubowskiego, nie ustrzegę się spojrzenia zabarwionego moją przeszłością, chociaż jako przewodniczący KRASP staram się maksymalnie obiektywizować mój punkt widzenia. Ocena, na ile mi się to udaje, oczywiście nie należy do mnie. Trzeba przy tym podkreślić, że w Polsce mamy bardzo rozbudowane (aktualnie ponad 400 szkół wyższych) i niezwykle zróżnicowane szkolnictwo wyższe. Zróżnicowanie to ma miejsce w kilku płaszczyznach przecinających się nawzajem. Najważniejsze z nich to różnorodność uczelni ze względu na charakter akademicki i nieakademicki, publiczne i niepubliczne, a także uwidocznione zazwyczaj w nazwie określenie ich dominującego charakteru w działalności dydaktycznej i co za tym idzie - naukowej, w tym branżowej (np. uczelnie wojskowe). Często jednak nazwy te nie odzwierciedlają w pełni obecnego obszaru ich działalności, są użyte czasem na wyrost, ale częściej są wynikiem tradycji i historii rozwoju. Szczególną specyfikę mają oczywiście uczelnie artystyczne. Ogranicza to znacznie ogólność wszelkich rozważań.

Odnosić się więc będę przede wszystkim do uczelni akademickich (według klasyfikacji European University Association - EUA), które mają uprawnienia do doktoryzowania (według EUA wystarcza jedno uprawnienie), chociaż w wielu miej- 
scach będzie to dotyczyło znacznie szerszej grupy uczelni, w tym wyższych szkół zawodowych.

\section{Refleksja pierwsza. Doskonałość naukowa i dydaktyczna - wzajemne relacje}

Jest to wielkie wyzwanie, realizowane $\mathrm{w}$ bardzo różny sposób na uczelniach na całym świecie. Gdybyśmy jednak skupili się na tych najlepszych, które mogą być wzorem, to i tam znajdziemy wielką różnorodność modeli. Zagadnienie to wiąże się bezpośrednio z odpowiedzią na pytanie, co jest źródłem najwyższej jakości procesu dydaktycznego (doskonałość dydaktyczna). Jeszcze raz zwrócę uwagę, że dochodzenie do tego stanu to niezwykle zróżnicowany proces zależny od typu uczelni, w ramach szeroko rozumianych uniwersytetów, zróżnicowany również pomiędzy kierunkami studiów. Potwierdzają to moje obserwacje i wiele przykładów, które można by przytaczać, ale jak sądzę w miarę zorientowany czytelnik przywoła je sobie, porównując np. kształcenie wybitnych chirurgów, filozofów, prawników, pedagogów czy informatyków. Proces ten wymyka się moim zdaniem możliwości opisu w jednym, nawet obszernym dokumencie typu ustawa czy zarządzenie. Są jednak takie cechy procesu, które mogą być uznane za uniwersalne. Najważniejszym z nich są ludzie - liderzy o wielkim doświadczeniu, wrażliwości na cechy osobowe osób kształconych czy całych ich grup, „czytających” ich możliwości percepcji, zdolność otwarcia się i chłonięcia wiedzy, ciekawość świata, ale także zdolności (talenty) określonego rodzaju, zależnie od kierunków studiów. Wrażliwość to wielka umiejętność, która połączona z odpowiednimi warunkami prowadzenia dydaktyki (bardzo zróżnicowanymi) i poziomem wiedzy podstawowej posiadanej przez słuchaczy daje wyśmienite efekty, które prowadzą wprost do tej doskonałości. Oczekiwane i uzyskane efekty są różne, w zależności od tego, czy prowadzimy kształcenie masowe (różnie rozumiane w różnych obszarach kształcenia), które ma miejsce zazwyczaj na pierwszych latach studiów, czy też mówimy o kształceniu specjalistycznym i elitarnym. Jeżeli dołożymy do tego wymóg naszych czasów, tj. kształcenie interdyscyplinarne, a nawet międzyobszarowe, to proces dochodzenia i realizacja jak najwyższej jakości kształcenia (tak rozumiem doskonałość dydaktyczną), zwłaszcza przy uwzględnieniu zmian otaczającego naszych absolwentów świata o niespotykanej dotychczas dynamice, stają się ogromnym wyzwaniem. Efekty można ocenić dopiero po wielu latach funkcjonowania naszych absolwentów na rynku pracy, co czyni ten obszar działalności uniwersytetu (najważniejszy!) trudny do szybkiej (w miarę) oceny i powoduje, że te oceny są bardzo stabilne. Dobrze opiniowani pozostają w takim stanie długie lata, trudno to zmienić (zepsuć), ale jeszcze trudniej uzyskać, a w szczególności odzyskać! 
Dlatego też podstawy tej działalności muszą być bardzo solidne, stanowiąc źródło jakości dydaktyki. W mojej ocenie głównymi jej składowymi są liczące wiele pokoleń studentów i dziesięcioleci działalności szkoły dydaktyczne oparte na tradycji dążenia za wszelką cenę do wysokiej jakości kształcenia, znajdowanie „talentów” dydaktycznych i otwartość na nowe formy procesu kształcenia (co nie jest takie proste), a przede wszystkim, zwłaszcza w kształceniu specjalistycznym i elitarnym, oparcie kształcenia na bardzo głębokiej, nowoczesnej wiedzy naukowej nauczycieli, a wręcz niezbędności w przypadku tego rodzaju studiów prowadzenia badań naukowych. Nie zawsze odnosi się to do poszczególnych osób, ale do konieczności istnienia środowiska naukowego, w którym prowadzona jest dydaktyka w danym obszarze. Dotyczy to codzienności dyskusji naukowych (seminaria, konferencje, proces badawczy) a także atmosfery nowości i nowoczesności, w której „zanurzony” jest proces dydaktyczny.

Decydują oczywiście ludzie, ich wiedza i cechy osobowe (talenty), ale wyjście od badań naukowych do procesu dydaktycznego i powiązanie dydaktyki z otoczeniem badawczym na wysokim poziomie uważam za niezbędny warunek doskonałości dydaktycznej.

Oczywiście stan ten będzie w różnym stopniu dotyczył różnego typu uczelni, i to zarówno w płaszczyźnie tematycznej, jak i rodzaju kształcenia (masowe, elitarne), poziomu kształcenia (licencjat/inżynier, magister) czy w końcu rodzaju uczelni (szkoła wyższa, akademia, uniwersytet).

I końcowe przemyślenia:

Doskonałość dydaktyczna to stan, do którego dochodzi się w danym obszarze kształcenia latami. Bardzo trudny do jednoznacznej i w miarę szybkiej oceny, a jednak po wielu latach pracy naukowej i dydaktycznej czujemy wszyscy wagę tego problemu i rozumiem, że nauczyciele akademiccy tworzący tę doskonałość to osoby o najwyższych kwalifikacjach i talencie naukowo-dydaktycznym. Powinni być nie tylko doceniani, ale także mieć stworzone przez uczelnie możliwości samorealizacji i bez żadnych ograniczeń osiągać najwyższe zaszczyty.

Konieczny jest rozwój form dydaktycznych i systemów promowania tych form, adekwatnych do systemów europejskich i światowych, a także wymagań otoczenia gospodarczego (tylko część uczelni: techniczne, przyrodnicze, ekonomiczne, pedagogiczne, częściowo uniwersytety „klasyczne”).

Bardzo ważnym i dość zróżnicowanym elementem jest w większości obszarów kształcenia tempo dokonywania przeobrażeń systemu kształcenia i metod dydaktycznych.

Jest ono wywołane dynamiką zmian zewnętrznych, ale także zrozumieniem, że na rynku pracy w ciągu najbliższych 10-20 lat nastąpią znaczące zmiany. Wszechogarniająca nas sieć teleinformatyczna o coraz wiekszych możliwościach, a w przewidywanej, piątej jej generacji (sieć $5 \mathrm{G}$ ) ucząca się, a wręcz tworząca z informacji elementy wiedzy, tj. stanowiąca rozmyte elementy sztucznej inteligencji, połączone 
z dynamiką rozwojową cyfryzacji naszego życia (rozumianej jako narzędzia elektroniczne + sieć + oprogramowanie), tworzy zupełnie nową tkankę dydaktyczną. Powszechny i latwy dostęp do zróżnicowanej w swej treści informacji to wielka wartość, ale i wielkie wyzwanie dla uczących się, a absolwenci naszych uczelni muszą nabyć nie tylko umiejętności poruszania się w tym świecie i zdolności oceny tych informacji, ale także skutecznego wykorzystywania tych narzędzi.

Rynek pracy będzie się zmieniał. Według wielu publikowanych ocen w ciągu najbliższych 20-30 lat zniknie ok. 40\% obecnie uprawianych zawodów. Pojawią się za to nowe. Automatyka i robotyka, połączone z szeroko rozumianą cyfryzacją, zlikwidują udział człowieka w wielu, nawet bardzo wyrafinowanych procesach i zawodach. Nasz absolwent będzie często zmieniał swój zawód, miejsce pracy, środowisko. Coraz częściej jako dobrze wykształcony członek społeczeństwa wiedzy będzie realizował złożone zadania ubrane w formę projektu (na marginesie: to słowo, często obecnie nadużywane, zrobiło furorę i nabrało wielorakiego znaczenia), będącymi kolejnymi wielkimi wyzwaniami, przed którymi stanie za 10-15 lat, a może już jutro w swojej pracy zawodowej.

To wymusza zwrócenie się do nowych, dotychczas niedocenianych form kształcenia - ogólnie zwanego projektowym (design thinking), a także szerokiego korzystania z sieci i kształcenia na odległość (mass open orienteg courses - MOOC), kształcenia z wielkim udziałem samokształcenia wymuszającego wręcz kreatywność i innowacyjność w myśleniu i działaniu. Dodatkowo konieczność kształcenia się przez całe życie (Longlife Learning - LLL). To trudne, ale niezbędne już dzisiaj umiejętności. Musimy je kształtować.

Przed nami więc poważne wyzwania w procesie kształcenia zarówno kadr naukowych i gospodarczych, jak również elit narodów i społeczeństw - a przecież to nasze główne i najważniejsze zadanie. Jakże odpowiedzialne.

\section{Refleksja druga. \\ Samodzielność naukowa - mity i uwarunkowania - powiązanie ze stopniem naukowym}

Samodzielność naukowa wzbudzała i wciąż wzbudza dyskusje, czasem bardzo gorące, bodajże największe obok dyskusji dotyczącej wyłaniania władz i kształtowania struktury uczelni.

Historyczne rozumienie tego pojęcia, często dzisiaj pokutujące, wiązało się z pojęciem samodzielnego pracownika naukowego. Pojęcie to jest dzisiaj coraz rzadziej stosowane formalnie i używane w potocznym rozumieniu. Dzisiejsze pojęcie samodzielności naukowej to określenie stanu wiedzy, stopnia opanowania warsztatu naukowego oraz poczucia odpowiedzialności, polegającego na trafnym i odważnym często formułowaniu zadań i projektów naukowych. Skutkuje to kierowaniem tymi 
projektami (po uzyskaniu ich finansowania) z sukcesem i tworzeniem wokół siebie zespołu mniej lub bardziej doświadczonych bądź wcale niedoświadczonych badaczy (w tym studentów i doktorantów). Stan taki osiąga się zazwyczaj po uzyskaniu stopnia doktora, ale dzisiaj czasami także magistra (sporadycznie wcześniej). Dziś to tak naprawdę jedyny wyznacznik tej samodzielności. Nieuchronnie wiąże się to z dyskusją nad utrzymaniem bądź nie drugiego stopnia naukowego - habilitacji. Wrosła ona w nasz krajobraz naukowy, a poza niektórymi ograniczeniami (przy daleko posuniętej autonomii uczelni - będzie o tym decydował statut) co do pełnienia określonych funkcji daje uprawnienia do „prokreacji naukowej”, tj. promowania doktorów, oraz udział w opiniowaniu/recenzowaniu w procesie habilitacyjnym i uzyskiwaniu tytułu naukowego. Są to więc bardzo specjalne i chyba wymagające tego stopnia, tj. dr. hab., uprawnienia. Poniżej, aby to lepiej zobrazować, w skondensowanej formie przedstawiam moje porównanie tych stopni wraz z komentarzem.

Pragnę zaznaczyć, że wynika ono z subiektywnego spojrzenia ukształtowanego w szkole naukowej w dziedzinie nauk technicznych i dla innych dziedzin może i powinno być zmienione lub/i uzupełnione. Nie wpływa to jednak na stopień ogólności i uniwersalności głównych myśli tam zawartych.

\subsection{Doktorat}

Doktorat jest stwierdzeniem samodzielności naukowej poprzez wykazanie przez doktoranta, że:

- posiada umiejętności przygotowania prac do przedstawienia w literaturze/ piśmiennictwie (wcześniejsze publikacje);

- potrafi jasno, zwięźle i trafnie sformułować problem o cechach oryginalnych, a więc dotychczas nierozwiązany teoretycznie lub/i praktycznie według doniesień literaturowych $\mathrm{w}$ danym obszarze, dziedzinie czy dyscyplinie naukowej (jest to stopień naukowy);

- dokonał krytycznego przeglądu literatury naukowej/piśmiennictwa, wyciągnął uprawnione wnioski dowodzące trafności i wysokiej wartości podjęcia proponowanego tematu formatującego/analizującego problem;

- właściwie dobrał metody i narzędzia umożliwiające jego rozwiązanie (realizację tematu), co może (ale nie musi) być krótko sformułowane poprzez tezę rozprawy (tradycyjny, klasyczny model rozprawy doktorskiej);

- używając właściwych i wystarczających do podjęcia danego tematu (w zakresie dostępnym w danym czasie i warunkach), rozwiązał sformułowany oryginalny problem (zrealizował temat) i potrafił wyciągnąć uprawnione wnioski: oryginalne lub/i nowe w skali literatury/piśmiennictwa światowego;

- potrafił określić zakres przydatności rozwiązania problemu dla danej dziedziny czy dyscypliny oraz pokazać implikacje wynikające z realizacji pracy. 
Cechą główną doktoratu jest więc analiza naukowa i/lub rozwiązanie problemu wraz z uprawnionymi, oryginalnymi wnioskami.

\subsection{Habilitacja}

Habilitant powinien wykazać się dotychczasowym, znaczącym i samodzielnym dorobkiem naukowym.

Habilitacja na pewno nie jest kolejnym doktoratem (nawet „większym” obszarowo i tematycznie). Habilitant musi wykazać, że potrafi dokonać syntezy wiedzy, którą nabył w trakcie prowadzonych badań, co pozwoliło mu na określenie nowych, często oryginalnych kierunków czy obszarów badawczych, wymagających dalszych, nierzadko zespołowych badań. To pozwala habilitowanemu na przemyślany i świadomy proces „reprodukcji” naukowej poprzez promowanie kolejnych doktorów i wnoszenie znaczącego wkładu w rozwój danej dziedziny czy dyscypliny naukowej, a także kompetentne i obiektywne recenzowanie i opiniowanie osiągnięć innych naukowców zarówno w procesie doktoryzowania, jak i habilitowania.

Ważnym elementem w przypadku habilitacji jest ocena osobowości habilitanta, nie tylko jako naukowca, ale jako człowieka o zdolnościach budowania zespołu i przewodzenia temu zespołowi czy kierowania projektami, a także budowania relacji mistrz - uczeń.

Cechą główną habilitacji jest więc synteza wiedzy, zwłaszcza zdobytej w wyniku badań własnych, i określenie nowych kierunków czy obszarów badawczych.

$* * *$

Te sformułowania nabierają nieco innego znaczenia w poszczególnych dziedzinach naukowych, ale są w miarę uniwersalne i mieszczą się w nich także procesy związane z wdrażaniem wyników prac badawczych do praktyki gospodarczej.

Reasumując, przygotowanie do samodzielnej pracy naukowej uzyskuje się po uzyskaniu stopnia doktora, a habilitacja to prawo do pełnej samodzielności, tj. promowania kadry i opiniowania niektórych wniosków.

W procesie uzyskiwania samodzielności naukowej elementem niezwykle istotnym jest mobilność naukowa, w tym system staży podoktorskich.

W dodatku zamieszczam dwie koncepcje realizacji programu zatytułowanego „Studia dla Wybitnych” (SdW), jakie opracowaliśmy wraz z prof. Andrzejem Kraśniewskim z Politechniki Warszawskiej (oczywiście za jego zgodą).

Jest to jedna z możliwych obecnie propozycji dotycząca praktycznej realizacji możliwości młodych naukowców w polskich warunkach.

Dotyczy to oczywiście całego okresu pracy, ale szczególnie ważne dla dalszego rozwoju młodych doktorów jest poznanie innych środowisk i metodyki pracy naukowej i dydaktycznej poza macierzystą jednostką. 


\section{Refleksja trzecia. Odnawianie kadry - warunek rozwoju}

Odnawianie kadry w sposób ciągły, zarówno w procesie badawczym, jak i kształceniu, to bodaj najważniejszy obecnie problem, z którym słabo sobie radzimy od lat. Dowodem jest już kolejna rysująca się na wielu uczelniach luka pokoleniowa. Należy jednak pamiętać, że w tym obszarze zależy nam wyłącznie na osobach o bardzo wysokich kompetencjach i nieczęsto spotykanych zdolnościach, utrzymujących wysokie normy moralne, osobach pełnych chęci i zapału do tej ciężkiej pracy, gotowych w tym zakresie do wielu wyrzeczeń, a wręcz poświęceń. To bardzo wysokie wymagania, których w żadnym stopniu nie jesteśmy w stanie (w większości uczelni) uwzględnić w wysokości wynagrodzeń. Chciałbym też zwrócić uwagę na fakt, że przy takich wymaganiach (często trudnych do jednoznacznej oceny) zdarzają się błędy już na początku tego procesu (popełniane przez kierownictwo jednostek, ale i przez kandydatów), a ponadto życie pisze swoje scenariusze. Każdy z nas w większym lub mniejszym stopniu z czasem się zmienia i nie jesteśmy w stanie wszystkiego przewidzieć. Dlatego też na każdej uczelni muszą być tworzone warunki prawne, a także ekonomiczne i po prostu ludzkie, w tym socjalne, które uwzględniałyby zarówno możliwość dokonywania odpowiednich wyborów przy doborze kadry na każdym etapie tego procesu, jak również ciągłości rzetelnej oceny każdego z nas i dokonywania korekt, aż do bezkonfliktowych (o ile to w ogóle możliwe) rozstań.

Piszę o tym bardzo delikatnie, bowiem materia jest wrażliwa, a przecież dotyczy to życia każdego z nas i naszych rodzin. Wydaje się, że stosowana w wielu uczelniach na świecie forma konkursów lub searchingu (przepraszam za anglicyzmy) przy zatrudnianiu kogokolwiek to dobra metoda. Gdyby towarzyszyła temu forma kontraktowa zatrudnienia, z możliwością w pewnym momencie pełnej stabilizacji zatrudnienia, i uwzględniało to polskie prawo, traktując takie zatrudnienie jako lex specialist (ze wszystkimi tego konsekwencjami), byłaby to forma najmniej dotkliwa dla pracownika i pracodawcy, a jednocześnie wychodząca naprzeciw stawianym przez rodzaj pracy wymaganiom.

Niezbędna w tej sytuacji (jak zresztą w każdej innej) jest realizacja rzetelnej oceny - coroczna, i jako kamień milowy, np. co 4 lata. Powinna ona doprowadzić do wyboru całościowej ścieżki kariery zawodowej każdego z nas, w każdym z obszarów działalności uczelni, z możliwością płynnego przechodzenia z jednego do drugiego czy w efekcie rozstania się. Rolę tę spełnia oczywiście w dużej mierze proces doktoryzowania i uzyskanie (lub nie) stopnia doktora, ale obecnie także proces habilitacyjny i uzyskanie (lub nie) stopnia doktora habilitowanego. Pisałem już o tym wcześniej (Refleksja druga), ponieważ jednak temat utrzymania habilitacji, zwłaszcza w kontekście stabilizacji zatrudnienia, jest wciąż dyskutowany i przez wielu kontestowany, zwracam na to uwagę i jeżeli habilitacja będzie procesem fakultatywnym, 
musimy zdecydowanie podnieść poziom i znaczenie ocen pracowników, zwłaszcza naukowo-dydaktycznych i naukowych.

Szczególną rolę w całym tym procesie powinna odegrać mobilność młodych pracowników nauki, w szczególności doktorantów i osób zaraz po uzyskaniu stopnia doktora (por. dwie, umieszczone w załączniku do niniejszych refleksji koncepcje realizacji programu zatytułowanego „Studia dla Wybitnych”).

Problemy te powinny znaleźć (podobnie jak inne zagadnienia z zakresu specyfiki pracy w szkole wyższej) swoje usankcjonowanie w przepisach prawnych, w szczególności w prawie pracy.

Zwróciłbym jednak uwagę, że w krytycznych momentach wynikających ze stosunków pracownik - pracodawca w szkole wyższej nie powinniśmy takiego pracownika pozostawiać wyłącznie jego losowi (zwłaszcza po wielu latach skutecznego i efektywnego zatrudniania).

Tutaj po raz kolejny przejawia się specyfika pracy i skutecznej realizacji celów, a także misji uczelni. W różnych krajach, o różnych możliwościach, w tym przede wszystkim ekonomicznych, rozwiązywało się i rozwiązuje ten problem w różny sposób. Wpływa na to wiele czynników, głównie względy ekonomiczne i możliwości finansowe pracodawcy. Istotny wpływ na te rozwiązania ma czasami tradycja związana z realizacją tych procesów, specyficzna w różnych instytucjach naukowych. To bardzo ważny, a zarazem delikatny problem. Sądzę, że bez pomocy państwa (prawodawstwo, finanse) pojedyncze uczelnie same sobie z nim skutecznie nie poradzą.

\section{Refleksja czwarta. Współpraca z gospodarką i administracją państwową. Komercjalizacja wyników badań}

Moje przemyślenia na ten temat w znacznym stopniu zabarwione są moim politechnicznym wykształceniem i całą drogą zawodową związaną z rozwojem przyszłościowych technologii. Nie może być więc ona w pełni obiektywna, ale będę się starał sprostać temu zadaniu.

Komercjalizacja wyników badań to wręcz fundament rozwoju każdej gospodarki, każdego ekosystemu. Dlatego też warto poświęcić temu zagadnieniu kilka uwag. Jest to proces zawsze obarczony skończonym i często trudnym do określenia prawdopodobieństwem sukcesu - zwłaszcza na początku drogi. Działalność w tym zakresie jest więc bardzo kosztowna, a w różnych działach gospodarki może pochłonąć kwoty sięgające miliardów dolarów (przykładem może być przemysł farmaceutyczny). Oczywiście sukcesem jest wprowadzenie na rynek produktów, które zabezpieczone odpowiednimi patentami pozwolą odzyskać środki z nieudanych, zarzuconych procesów komercjalizacji i osiągnąć odpowiednią stopę zysku. Jestem przekonany, że proces ten nie zawsze w naszych warunkach jest rozumiany w ten 
globalny sposób. Często mamy do czynienia (i tego oczekujemy) z komercjalizacją osiągnięć w znacznie mniejszym zakresie, na znacznie mniejszą skalę, jako wynikiem wspólnych działań nauki i przemysłu.

Przyjmijmy ten punkt widzenia. Gdzie jest miejsce uczelni? Trzeba stwierdzić, że procesy te dotyczą tylko niektórych uczelni (zwłaszcza technologicznych, przyrodniczych, częściowo medycznych czy ekonomicznych, i innych, w ograniczonym obszarze tematycznym). Nie wszystkie i nie w pełnym zakresie swojej działalności mogą więc być brane pod uwagę.

Te, które mają realne możliwości osiągnięcia sukcesu, to te odkrywające nowe możliwości technologiczne czy „tajemnice przyrody”, co prowadzi do powstania „przełomowych technologii”. Dyrektor Instytutu Fraunhofera prof. Reimund Neugebauer w ciekawym wywiadzie przeprowadzonym przez redaktora Waldemara Siwińskiego (Perspektywy, 6/2017) uznał to za jeden z trzech głównych celów nauki, w szczególności europejskiej. To domena badań tzw. podstawowych, realizowanych głównie przez bardzo silne ośrodki naukowe, a w nich mocne, zintegrowane grupy badawcze na uniwersytetach (zwłaszcza „klasycznych”). To prapoczątek wszystkiego, dlatego te badania o ogromnym ryzyku jakiegokolwiek sukcesu mogą być prowadzone wyłącznie przy udziale mecenatu publicznego lub bardzo silnych firm, które mają to zapisane w strategii rozwojowej. Czasami mogą być finansowane specjalnymi kredytami bankowymi, o wysokim stopniu ryzyka, i wymagają wielkiego zaufania ze strony inwestora. W Polsce taką rolę spełnia Narodowe Centrum Nauki.

Ale to przecież dopiero początek.

Wiele czołowych uniwersytetów na świecie nie posuwa się dalej, skupiając się na procesie kształcenia. Dotyczy to zwłaszcza tych, które w swej działalności badawczej będą w stanie podjąć kolejne oryginalne, przełomowe badania podstawowe. Mamy również takie uniwersytety w Polsce, a naprawdę ich części. Głównym i bardzo kosztownym, a zarazem obarczonym również dużym ryzykiem, jest proces przetwarzania pomysłów i oryginalnych rozwiązań technologicznych na poziom demonstratora technologii, ewentualnie prototypu urządzenia, układu, systemu itp. To pierwsza część w ujęciu ekonomicznym tzw. „doliny śmierci” i początek prawdziwych, często bardzo dużych nakładów finansowych na opracowanie powtarzalnej technologii czy realnego określenia cech użytkowych urządzenia, systemu itp. Tutaj już musimy prowadzić badania rynku i zabezpieczać swoje interesy, np. poprzez patenty, a przede wszystkim zainteresować tym przyszłych producentów/inwestorów. Takie działania muszą być prowadzone w realnych warunkach technologicznych, często na liniach doświadczalnych - a więc dużych, zintegrowanych centrach badawczo-rozwojowych. Jako przykład może posłużyć Centrum Zaawansowanych Materiałów i Technologii w Warszawie czy EITT+ we Wrocławiu. Zachęcam zainteresowanych do odwiedzenia tych ośrodków. Ta część całego procesu komercjalizacji to obecnie jego najsłabsze ogniwo. W polskich warunkach bardzo trudno uzyskać finansowanie tego etapu, w zasadzie obecnie brak jest systemowego finansowania 
tej części „doliny śmierci”. Na dalszym etapie można i należy już oczekiwać finansowania ze strony przemysłu (choć obecnie, ze względu na wciąż duże ryzyko inwestycyjne, w ograniczonym zakresie i w szczególnych przypadkach). Tak więc bez zdecydowanego mecenatu państwa w zakresie prac badawczo-rozwojowych (tzn. pierwszej części „doliny śmierci”) powstaje luka w finansowaniu całego łańcucha prac prowadzących do komercjalizacji osiągnięć. To była jeszcze kilka lat temu domena Narodowego Centrum Badań i Rozwoju, i chyba taką pozostanie, jednak zakres finansowania tego typu badań jest obecnie bliski zera. To bardzo niebezpieczny stan, przerywający ciąg zdarzeń prowadzących do realnego zainteresowania przemysłu, co powinno w efekcie pomóc podjąć decyzję o zainwestowaniu we wprowadzenie (lub nie) produktu na rynek. Jaka jest rola uczelni, zwłaszcza o charakterze technologicznym? Bardzo duża, a w pierwszej części prac z obszaru „doliny śmierci” dominująca. Trudno tutaj liczyć na finansowanie inne niż ze strony państwa. Brak tego finansowania za kilka lat odbije się negatywnie w działalności polskich jednostek naukowych i bardzo utrudni, by nie powiedzieć uniemożliwi, skuteczną komercjalizację ich osiągnięć. W efekcie przyniesie także trudne do odwrócenia skutki zarówno w procesach kształcenia kadry technologicznej i konstrukcyjnej, jak i wykorzystania starzejącej się infrastruktury. Efekt może być wręcz katastrofalny dla całego ciągu zdarzeń, o których piszę. Proces komercjalizacji w całości jawi się jako wielkie wyzwanie stricte gospodarcze z koniecznym udziałem finansowania ze strony państwa. Uczelnie powinny i są zobowiązane brać udział w całym tym procesie, angażując do niego zarówno badaczy, doktorantów i studentów, jak również kadry ekonomiczno-administracyjne (co dzieje się na wielu uczelniach), ale w pojedynkę podjąć się skutecznie tego wyzwania nie mogą, a nawet nie powinny. Czy Ustawa 2.o powinna się do tych problemów odnosić? Raczej nie, albo w bardzo ogólny sposób.

Sam proces komercjalizacji, tak ważny dla rozwoju Polski, powinien być stymulowany poprzez akty prawne związane z działalnością gospodarczą (wyraźnie określając rolę naukowców i jednostek naukowych,- w tym uczelni) oraz zabezpieczać ich interesy, w tym prawo do własności intelektualnej czy przemysłowej. Te prace zresztą, głównie na poziomie ustawowym, są w toku. Czy zapewnią skuteczną realizację całego procesu? Miejmy nadzieję i nabierzmy przekonania, że tak.

\section{Refleksja piąta. Uczelnie jako bardzo złożony ekosystem - etos, autonomia, ustrój i zarządzanie}

Uczelnia to specyficzny rodzaj instytucji, w której realizowane są jako podstawowe przede wszystkim dydaktyka i badania naukowe, ale także wielka szkoła charakterów i - nie boję się użyć tego słowa - jednostka wychowawcza, kształtująca cha- 
raktery młodych ludzi, jednocześnie ludzi dorosłych i w pełni odpowiedzialnych za siebie (chociaż w sferze ekonomicznej często zależnych od rodziny). Ta funkcja realizowana jest w dwóch relacjach: relacji mistrz - uczeń, co przenosi się także poza sferę dydaktyczną i naukową, i w relacji z kadrą nauczającą i całą wspólnotą akademicką, w skład której wchodzą także ci najważniejsi: studenci i doktoranci. Ta grupa, często określana jako „brać studencka”, odgrywa ogromną rolę w kształtowaniu charakterów i postaw, często na całe życie. Dlatego tak ważne jest pobudzanie, podtrzymywanie i rozwój aktywności studentów i doktorantów w różnych obszarach oraz miejscach związanych z uczelnią: kluby studenckie, zespoły artystyczne, ale także koła naukowe i w końcu domy studenckie. To niezwykle ważny element realizowany w duchu roty przyrzeczenia studenckiego i wprowadzanej z wielką determinacją zasady neutralności politycznej uczelni. Uczelnia jest to mniejsza lub większa instytucja (ale w wielu przypadkach największy lub prawie największy pracodawca w regionie), prowadząca również wiele działań o charakterze gospodarczym (to konieczność ekonomiczna), ale także koordynator i wykonawca ważnych (wręcz kluczowych dla państwa) projektów (np. prowadząca obszerną działalność ekspercką). To wszystko realizowane jest $\mathrm{w}$ warunkach poszanowania tradycji i historii każdej z instytucji i wszystkich razem jako środowiska, z jednej strony bardzo różnorodnego (o czym było we wstępie), ale połączonego wspólnymi celami i co bardzo ważne, autonomicznych w wypełnianiu swojej misji i kultywujących z wielką pieczołowitością etos uczelni jako instytucji o najwyższych normach etycznych. Dotyczy to całego środowiska akademickiego, aż do poziomu kraju, ale także specyfiki regionu czy danej uczelni, aż do poziomu każdego z nas. Wielką rolę spełniają więc lokalne i globalne w skali kraju konferencje rektorów, kanclerzy i kwestorów, a także prorektorów, dziekanów, prodziekanów itd. - jako przedstawicieli poszczególnych wspólnot. To tam dyskutowane są nie tylko problemy istotne dla szkolnictwa wyższego, ale także właściwe wykorzystanie autonomii uczelni wraz z granicami tej autonomii, bowiem także oczywiście istnieją, dyskutowane są i oceniane problemy i postawy etyczne w duchu etosu uczelni jako niezwykle ważnej instytucji zaufania publicznego. Dotyczy to wszystkich uczelni i ma ogromne znaczenie i wpływ na kształtowanie przyszłych pokoleń (w tym elit społeczeństwa). Uczelnie traktowane są często jako swego rodzaju „sumienie narodu” i odgrywają wielką rolę w rozwoju cywilizacyjnym, w tym kulturowym.

Wracając do konferencji jednoosobowych organów uczelni, trzeba zaznaczyć, że szczególną rolę spełnia tu powołana w 1997 r. Konferencja Rektorów Akademickich Szkół Polskich (KRASP) - w bieżącym roku obchodziliśmy 20-lecie jej istnienia. Ukazało się z tej okazji wiele materiałów i wywiadów. Wiele na temat 20-letniej i bieżącej działalności KRASP można znaleźć w materiałach z Jubileuszowej Sesji KRASP (Posiedzenie Plenarne KRASP - Wrocław, 6-7 czerwca 2017) i w książce Uczelnie i sztuka rektorstwa. Doświadczenie i refleksje Jerzego Woźnickiego, opublikowanej przez wydawnictwo Wolters Kluwer - wywiadzie rzece ze współor- 
ganizatorem i najstarszym aktywnym byłym przewodniczącym KRASP. Zachęcam do tej ciekawej lektury.

Wracając na chwilę do autonomii i etosu uczelni, polecam materiały z konferencji zorganizowanej przez Instytut Problemów Współczesnej Cywilizacji im. Marka Dietricha wraz z Konferencją Rektorów Akademickich Szkół Polskich i Politechniką Warszawską, właśnie w Politechnice Warszawskiej 10 czerwca 2017 r. Ukażą się one we wrześniu br. i będą dostępne w formie zwartego wydawnictwa oraz na stronach internetowych organizatorów. Będzie to niewątpliwie ciekawa lektura, zwłaszcza plenarne wystąpienia zaproszonych referentów.

Tematyka właściwego tworzenia podstaw i wykorzystania autonomii uczelni na potrzeby realizacji jej misji i misji całego szkolnictwa wyższego nieodłącznie wiąże się z ustrojem i zarządzaniem uczelnią - $\mathrm{w}$ tym $\mathrm{z}$ wyłanianiem szeroko rozumianych władz uczelni, szczególnie rektora. Jest to istotne na wielu płaszczyznach działalności uczelni - o czym była mowa wcześniej, stąd nie jest możliwa analiza tych zagadnień w skondensowanej formie. Odsyłam do opracowania Komisji ds. Strategicznych Problemów Szkolnictwa Wyższego KRASP wraz z Fundacją Rektorów Polskich jako raportów z prac tej Komisji (Warszawa, czerwiec-lipiec 2017).

Zawiera on umiejscowienie tego problemu w zaproponowanej przez Komisję strukturze całej ustawy i jako jedyny jest obszernie zapisany w postaci paragrafów ustawy językiem prawniczym. Na ile i w jakiej formie zostanie on uwzględniony w Ustawie 2.o, trudno dzisiaj przesądzić, ale spotkał się z bardzo dobrym odbiorem wielu gremiów, w tym KRASP-u, kanclerzy i kwestorów uczelni członkowskich, Rady Głównej Szkolnictwa Wyższego, Rady Narodowego Kongresu Nauki.

Raporty te są dostępne na stronach internetowych KRASP-u i nie wymagają szerszych komentarzy. Chciałbym jednak zwrócić uwagę na podział kompetencji i odpowiedzialności rektora i kanclerza. To w moim odczuciu, wynikającym z praktyki, fundamentalne zagadnienie ustrojowe, a chyba zbyt mało wyraziste w cytowanych opracowaniach.

O ile nie mam wątpliwości co do zakresu kompetencji rektora jako osoby odpowiedzialnej za całość uczelni, o tyle uczyniłbym w ustawowym zapisie zakres zarządczy i jednoosobową odpowiedzialność kanclerza (z określeniem kompetencji osobowych decydujących o jego wyborze w drodze konkursu i powołaniu przez rektora) za całą gospodarkę majątkową, w tym sprawy własnościowe, terenowe, inwestycyjne i remontowe. Rektor powinien w tym zakresie być jedynie zobowiązany do kontrasygnaty, ponosić współodpowiedzialność za ten zakres zarządu uczelni. Sprawą otwartą jest pozycja kwestora jako ew. tylko głównego księgowego, z kompetencjami i odpowiedzialnością wynikającą z innych ustaw, czy też nałożenie nań obowiązków dyrektora finansowego odpowiedzialnego przed rektorem za całokształt polityki finansowo-ekonomicznej uczelni. Wtedy musiałby być umocowany także w ustawie. 
To oczywiście tylko garść spostrzeżeń, ale zagadnienia tylko „dotknięte” w tej Refleksji mają charakter fundamentalny dla kreowania wielu mniej lub bardziej szczegółowych kwestii dotyczących ustroju szkolnictwa wyższego.

\section{Dodatek \\ Załącznik do Refleksji trzeciej \\ Program „Studia dla wybitnych" (SdW): założenia i koncepcja realizacji (wstępny projekt)}

Jest możliwe i byłoby pożądane, aby przygotowany program docelowo obejmował propozycje wymienione zarówno w opisie koncepcji A, jak i koncepcji B.

\section{Koncepcja A}

Stypendia przyznawane w programie SdW służą finansowaniu staży dydaktyczno-badawczych odbywanych przez studentów znajdujących się w końcowej fazie kształcenia (na określonym cyklu kształcenia - studia pierwszego lub drugiego stopnia bądź jednolite studia magisterskie) w wiodących centrach badawczych polskich uczelni lub jednostek naukowych (instytutów PAN, instytutów badawczych) działających w różnych obszarach wiedzy ( $w$ tym centrach prowadzących badania w zakresie nauk humanistycznych i społecznych), w centrach badawczych firm działających na terenie Polski i ew. innych podmiotów.

Miejscem odbywania stażu jest centrum badawcze znajdujące się w znacznej odległości (co najmniej $100 \mathrm{~km}$ ?) od macierzystej uczelni studenta. W przypadku gdy centrum takie jest częścią innej uczelni lub jest związane z inną uczelnią ulokowaną względnie blisko centrum, odbycie stażu może być związane ze zmianą uczelni. Staż trwa jeden semestr lub jeden rok.

Stypendia przyznawane są w trybie konkursu ogłaszanego co semestr przez MNISW.

Stypendium obejmuje:

- wynagrodzenie (stałe/miesiąc - określone w warunkach konkursu; dostatecznie atrakcyjne, aby zachęcić najlepszych studentów do ubiegania się o staż),

- koszty utrzymania w innym mieście (stałe - określone w warunkach konkur$\mathrm{su}$ ),

- koszty prowadzenia badań (zmienne - materiały itp., określone we wniosku konkursowym składanym przez studenta).

Stypendia są przyznawane na wniosek studenta. Wniosek określa m.in.:

- miejsce odbywania stażu,

- okres odbywania stażu, 
- tematykę, zakres i przewidywane wyniki badań,

- sposób wykorzystania wyników badań, w tym w pracy dyplomowej; praca taka może być prowadzona na uczelni macierzystej lub uczelni stanowiącej siedzibę centrum badawczego bądź współpracującej z tym centrum - jeśli nie jest ono częścią uczelni),

- koszty prowadzenia badań,

- wstępną akceptację kandydata przez centrum, w którym ma być odbywany staż.

Wniosek zawiera też odpowiednie informacje (pozostaje do określenia jakie) umożliwiające stwierdzenie, że mamy do czynienia ze studentem wybitnym.

Oceny wniosków dokonuje komisja konkursowa powołana przez ministra nauki i szkolnictwa wyższego.

Minister nauki i szkolnictwa wyższego określi wymagania, jakie musi spełniać instytucja oferująca staż. Wymagania te powinny dotyczyć w szczególności warunków prowadzenia badań stworzonych studentowi (wyposażenie w aparaturę, stymulujący rozwój zespół naukowy itd.); można też rozważyć preferencję dla centrów badawczych, których utworzenie lub wyposażenie sfinansowano z programów europejskich.

Instytucje zainteresowane pozyskaniem studentów będących beneficjentami programu SdW składają oferty staży, które umieszczane są w bazie danych nadzorowanej przez MNiSW. MNiSW sprawuje nadzór nad formalnymi aspektami ofert.

Zalety/uzasadnienie przedstawionej koncepcji:

- stwarzamy studentom znakomite warunki zdobywania wiedzy i kompetencji związanych z realizacją idei kształcenia opartego na badaniach (research-based education),

- wspieramy mobilność (ze wszystkimi jej zaletami - zetknięcie z nowymi ideami, zwiększenie możliwości „rozwoju interdyscyplinarnego),

- ułatwiamy „rozruch” i utrzymanie infrastruktury badawczej sfinansowanej z programów europejskich.

Koncepcję tę może wspomagać podwójna opieka nad studentem (wspólne promotorstwo pracy dyplomowej) - przez osobę z macierzystej uczelni i osobę z centrum, w którym odbywany jest staż.

Stypendia przyznawane w programie SdW służą wspieraniu szeroko rozumianej mobilności studentów, tak zagranicznej (wyjazdy typu Erasmus+), jak i krajowej (MOST, MOSTECH itd.). Program jest rozszerzony na doktorantów.

Na wzór programu TOP 500 Innovators organizowane są wyjazdy studentów na 4-8-tygodniowe staże zagraniczne w wiodących uczelniach zagranicznych, silnie powiązanych z otoczeniem społeczno-gospodarczym (Stanford University, EPFL Lausanne, University of Cambridge, NTU Singapore), obejmujące kursy (np. z zakresu przedsiębiorczości, organizacji pracy zespołowej, tworzenia start-upów, projektowania zgodnie z metodyką design thinking), a także wizyty w firmach. Studenci podczas takiego wyjazdu realizowaliby miniprojekty oraz jeden duży projekt. 


\section{Koncepcja B}

Następuje zmiana nazwy programu na „Innowacyjni w kształceniu”, w intencji włączenia do grona beneficjentów programu doktorantów oraz młodych (stażem?) nauczycieli akademickich. Jednym z głównych celów programu byłoby zainicjowanie zmiany na poziomie systemu - wprowadzania i upowszechniania innowacyjnego podejścia do kształcenia na poziomie wyższym.

Możliwe formy realizacji programu obejmowałyby:

- Finansowanie udziału doktorantów oraz nauczycieli akademickich w prowadzonych przez uczelnie zagraniczne studiach w zakresie nowoczesnych metod kształcenia. Przykładem takich studiów może być program studiów drugiego stopnia „Master in Problem Based Learning in Engineering and Science”, prowadzony przez Aalborg University (Dania) - wiodącą uczelnię w zakresie nowoczesnych form kształcenia, działającą pod patronatem UNESCO.

- Finansowanie udziału doktorantów oraz nauczycieli akademickich w prowadzonych przez uczelnie zagraniczne 4-8-tygodniowych kursach dokształcających i innych formach doskonalenia zawodowego nauczycieli akademickich w zakresie nowoczesnych metod i technik kształcenia, w tym w specjalistycznych kursach zorientowanych na wybrane obszary kształcenia, przygotowanych na zamówienie MNiSW. Proponowane uczelnie/instytucje europejskie: Aalborg University, Maastricht University, TU Eindhoven, Aalto University (Helsinki) oraz ewentualnie uczelnie w USA i Azji.

- Finansowanie 4-8-tygodniowych wyjazdów grup obejmujących nauczycieli akademickich, doktorantów i studentów do uczelni zagranicznych. W trakcie pobytu w tej uczelni nauczyciele i doktoranci - po odpowiednim wstępnym szkoleniu - prowadziliby pod opieką miejscowych trenerów/tutorów zajęcia (przede wszystkim warsztaty) z polskimi i miejscowymi studentami. Proponowane uczelnie/instytucje europejskie - jak wyżej.

Kompetencje uzyskane przez doktorantów oraz nauczycieli akademickich w wyniku udziału w programie służyłyby podniesieniu jakości kształcenia i zorientowaniu procesu dydaktycznego na studentów - pobudzaniu ich kreatywności i przedsiębiorczości.

\section{Discussion before the National Congress of Science - reflections}

ABSTRACT. The paper presents an analysis of selected topics discussed in the debates concerning science and higher education in the context of the draft law, called Law 2.o. In particular, the author selected the topics that dominated during the sessions of nine conferences organized before the National Congress of Science and council meetings of this Congress. Topics and their analysis are, of 
course, the point of view of the author and have been collected in the form of five reflections. Several proposals for detailed solutions were also presented - one in the form of a supplement to the study.

KEYWORDS: science, higher education, Law 2.0

CYTOWANIE: Szmidt, J. (2017). Dyskusja przed Narodowym Kongresem Nauki - refleksje. Nauka i Szkolnictwo Wyższe. 2(50): 315-331. DOI: 10.14746/nisw.2017.2.18.

JAN SZMIDT - prof. dr hab. inż., od 2012 r. rektor Politechniki Warszawskiej, przewodniczący Konferencji Rektorów Akademickich Szkół Polskich. Dziekan Wydziału Elektroniki i Technik Informacyjnych Politechniki Warszawskiej w latach 2008-2012. Przewodniczący i członek komitetów kilkudziesięciu międzynarodowych i krajowych konferencji. Specjalizuje się w dziedzinie elektroniki i technologiach półprzewodnikowych. Autor i współautor licznych publikacji naukowych. E-mail: jmr@rekt.pw.edu.pl. 